\title{
Education research from Vietnam as seen from ISI WoS between 1990 and 2018: some preliminary results
}

\author{
Anh Pham Thi Van \\ FPT University, Hanoi, Vietnam \\ Email: anhptv2@fpt.edu.vn
}

\section{An Do Thi}

Foreign Trade University, Hanoi, Vietnam

Email: dothian@ftu.edu.vn

\section{Hiep-Hung Pham}

Phu Xuan university, Hue, Vietnam

Email: phamhunghiep@gmail.com

\begin{abstract}
This paper analyzed data from 174 articles concerning educational research in Vietnam between 1990 and 2018 from Clarivate Web of Science (WOS) database, one of the most reputable indexed data banks for scientific outcomes. To attain the number of publications, all papers indexed in category of educational sciences under Clarivate WOS were extracted and then being filtered by both two authors. The results show that there was a significant increase in the number of papers published during this period with only 1 publication during 1990 and 1994 and quickly increased to 100 research papers during 2014-2018, after 20 years. "Teaching and learning" was found as the dominant research field while "Test and assessment" was paid aa least attention. There were much more papers in Higher education than in "Technical and vocational education and training" and "Early childhood education". Another remarkable finding is that the main source of publication was journal accounting for $52.84 \%$ of the total. The number of male and female authors contributing to the scientific work was relatively equal. Notably, the number of papers published in high quality journals was rare. Despite the growth in the total outputs, Vietnamese researcher should consider their effort in each scientific work.
\end{abstract}

Keywords: Vietnamese publications, international collaboration, ISI Web of Science

\section{INTRODUCTION}

"Education" theme is a fertile land that many researchers have exploited for many decades. However, there have not many articles published in the collaboration between Vietnamese and foreign authors. After Renovation (Doi Moi) period, with significant changes in investment policies for foreign languages, scientific reports and articles were promoted and improved with more emphasis placed on multi-national cooperation. According Nguyen and Pham (2011) and Manh (2015), over the past twenty years, the publications with careful peer review have risen the research activities up significantly. This is resulted from new policy and the normalization between Vietnam and America, which helps to increase the number of collaboration in publishing scientific papers. The collaboration between a new foreign partner and a Vietnamese author tends to boost the number of publications of Vietnamese author (Q. H. Vuong et al., 2018). From this reform, foreign language teachers going to work 
in Vietnam can cooperate with local teachers to write articles, or even people with a shared interest in certain research object can also cooperate with each other to create qualified research papers.

In the past, many researchers tried to draw an overview of publication output of Vietnam, using the data from some sources, for example, Hien (2010) used data from ISI index, Manh Ho (2015) wrote a summary about scientific publications in Vietnam, using Scopus information from 1996 to 2013. Vuong et al. (2018) utilized Scopus database, open online sources and self-reports of scientists to analyze a database on scientific productivity in Vietnamese's social sciences and humanities. Nonetheless, no studies have main focus on collaboration in education publications. In other word, this paper is an updated version when it can extend the time of investigating data in the period of 28 years, nearly 3 decades, from 1990 to 2018 with many unique discoveries. All articles are also taken from source Scopus; therefore, the reliability is secured. This review article will answer all questions such as how many articles are in the field during the proposed period, how the articles are broken down by each committee, or which areas, which schools in Vietnam have the most articles; which are the most popular keywords appearing in the articles. In addition, this review article can respond to questions related to the number of foreign cooperation studies in this education field.

The review was carefully gathered and analyzed by the authors with the hope that the article will reshape the overall picture of what happened in educational research within nearly 30 years. Researchers can rely on this review to understand which areas of research are under-exploited; thereby conducting research on those objects to enrich the research in general. Moreover, strong links with typical countries are also highlighted so that readers can understand the common cooperation context of our country and other nations in the world. When reviewing all educational publications in the period shown, it can be easily recognized that from macro issues such as school management, research in teaching to the teaching of each learning skill are reflected quite adequately in the authors' writing. However, the object of research and the scope of research have not been balanced among levels of education. For example, there are more articles about university level than that of lower levels.

To help readers to follow the paper easily, the authors divide this article into four main sections. The first one is introduction, and then materials and methods are explained in part two. Next, part three reveals results about characteristics of articles which are chosen, dominant research fields, most frequent words used in all investigated papers, research areas, top universities with the highest number of publication and other results about collaborations in writing educational products. Finally, the discussion section is presented after finishing all the sections as listed above.

The authors hope that the article, though limited in time and scope, can contributes practically to research work for young researchers in the future.

\section{MATERIALS AND METHODS}

\section{Data extraction and processing}

Data extraction and processing is an important step as it provides the next steps such as analysis, results and discussion with a firm foundation. Data were downloaded online through the Web of Science including accession number, doi, pubmed ID, article title, authors, source, research area, volume, issue, pages, publication date, times cited, link, journal expected citations, category expected citations, journal normalized citation impact, category normalized citation impact, percentile in subject area and journal impact factor followed by filtering process. Earlier, we had a long discussion about how to classify the papers. A suitable classification was not found after a lot of searching, which led to our decision to build our own version. The final decision was to divide all the articles into 8 different strands namely test and assessment, teaching and learning, education technology, 
curriculum, management-leadership and policy, psychology education, research and other and also 5 branches of education were considered (Early childhood education, Technical and Vocational Education and Training, General education, Higher education and Lifelong learning). Shortly afterwards, a new excel file was created to store all the data including article title, authors, research strand, branch of education, year of publication, journal impact factor, which were important for the analysis. Additionally, we downloaded "author keywords" and "author's affiliation" that were not included in the downloaded data. The data processing, initially, was done by the two authors separately. Each of us carefully read the title, the abstract and the key words of each paper, and then decided which strand and branch it belongs to. . Meanwhile, we had to pick up the needed information from the CSV file extracted from Web of science to fill in the created excel file. This review paper concerns the work about education and educational research, language and linguistics, so among 197 papers found, only the ones belonging to those topics were filtered. The papers which belongs to public, environmental and occupational health, business, finance, management, psychology, interdisciplinary, information science and library science and area study were excluded. After completing the individual work, we exchanged the work and check if there was any disagreement. Fortunately, there were not many conflicts between us except for some about the research strands. We then reached to an agreement after a discussion in person. Finally, 174 papers concerning education and educational research, language and linguistics were selected. The classification and information about these papers would be discussed in the next parts.

\section{RESULTS}

\section{Publications by year}

Among 197 papers that the authors found and downloaded, only 174 papers about education fields published from 1991 to 2018 are kept to analyze after a careful filtering process. The total number of paper released each year is carefully shown in the following table.

Table 1. Number of publications from 1991 to 2018

\begin{tabular}{|l|l|l|l|l|l|}
\hline $\begin{array}{l}\text { Year of } \\
\text { publication }\end{array}$ & $\begin{array}{l}\text { Number of } \\
\text { publications }\end{array}$ & $\begin{array}{l}\text { Year of } \\
\text { publication }\end{array}$ & $\begin{array}{l}\text { Number of } \\
\text { publications }\end{array}$ & $\begin{array}{l}\text { Year of } \\
\text { publication }\end{array}$ & $\begin{array}{l}\text { Number of } \\
\text { publications }\end{array}$ \\
\hline 1990 & O & 2001 & 2 & 2012 & 5 \\
\hline 1991 & 1 & 2002 & 0 & 2013 & 16 \\
\hline 1992 & O & 2003 & 0 & 2014 & 16 \\
\hline 1993 & $\mathrm{O}$ & 2004 & 3 & 2015 & 13 \\
\hline 1994 & $\mathrm{O}$ & 2005 & 2 & 2016 & 22 \\
\hline 1995 & $\mathrm{O}$ & 2006 & 4 & 2017 & 33 \\
\hline 1996 & $\mathrm{O}$ & 2007 & 0 & 2018 & 16 \\
\hline 1997 & $\mathrm{O}$ & 2008 & 4 & & \\
\hline 1998 & $\mathrm{O}$ & 2009 & 10 & & \\
\hline 1999 & $\mathrm{O}$ & 2010 & 15 & & \\
\hline 2000 & $\mathrm{O}$ & 2011 & 12 & & \\
\hline
\end{tabular}




\section{number of publications}

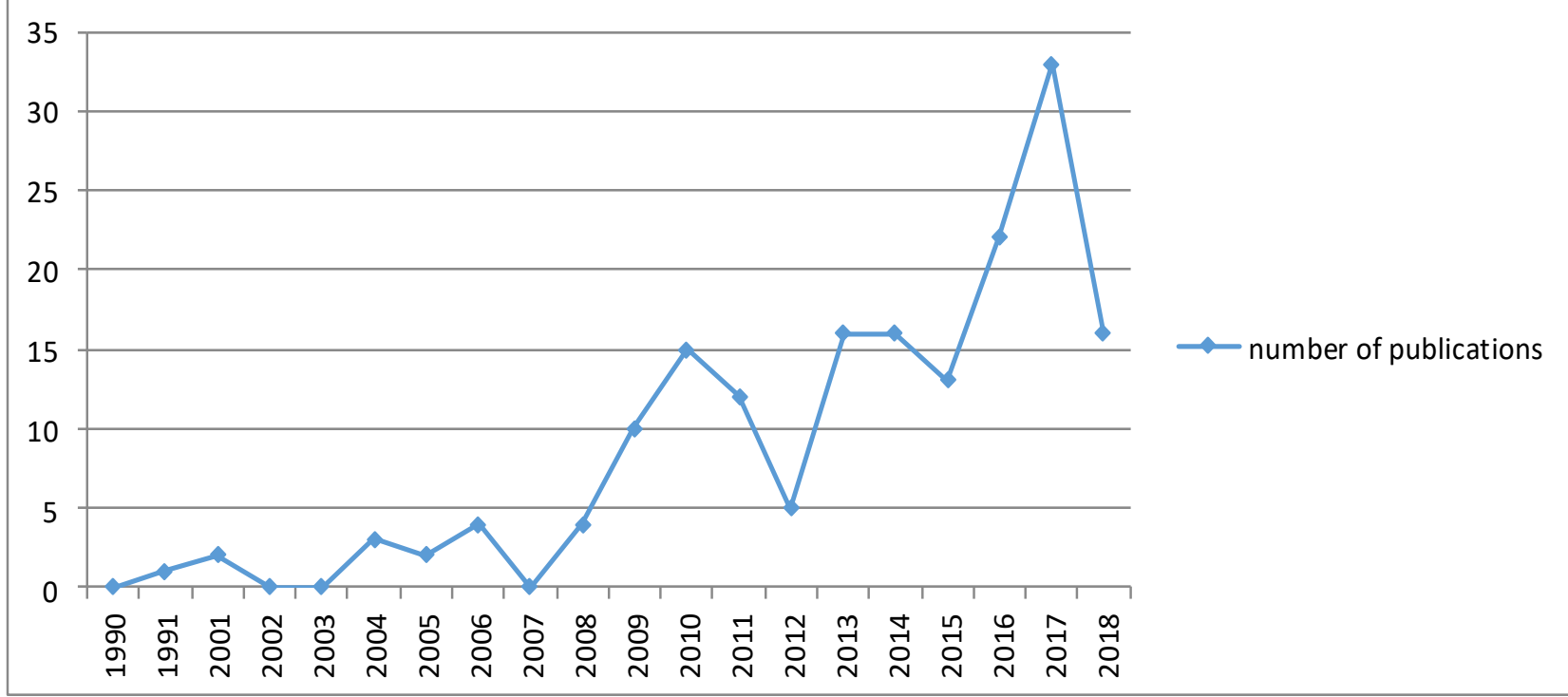

Figure 1. Number of publications from 1990 to 2018

From the table and the chart, it can be recognized that right after "Doi Moi"- Education Reform in Vietnam in 1986, there was no article published. In the next 5 years, only one paper was formally released. The milestone need to be noted here is that in the period of time from 1995 to 1990, it could not be found any publications about education field. This can be call the darkest time of education research. It was not until the year 2009 that the situation started to change positively when the number of articles recorded was 10. If in the period between 2000 and 2004, the total papers were 5, the next 5-year period from 2005 to 2009 , the articles in sum were 20, which grew up about 4 times compared to the former number. Since then, the number of articles published rose considerably time after time, and it caught number 64 in the years from 2010 to 2014.

The most blooming phase of education research, understandably, is the latest time. It was from 2015 to 2018 that the number of publication reached its highest peak in the recorded history. The higher growth of the national economy is, the more investments in education are formed. This results in the increase in both quantity and quality of research, especially on this pedagogical term.

\section{Research fields and levels of education}

Finding the top research fields most frequently concentrated is one the most challenging sections for both two writers, because there was no formal classification for fields in education studies before. Hence, the owners of this paper need to categorize strands without any reliance on the previous division. With our own effort and the thorough investigation, a measure form for classifying education research fields was created. According to this categorization, there are seven main fields, namely, 1) test and assessment, 2) teaching and learning, 3) technology in education, 4) curriculum, 5) management, leadership and policy, 6) psychology education, and 7) research. Those articles whose contents do not belong to one of the fields mentioned above are put into "other" category; for instance, "Across borders and across cultures", "Cultural Features of Vietnamese Personal Names". The statistic data about research fields is expressed in detailed in the following table and chart. 
Table 2. The number of publications in each education research field

\begin{tabular}{|l|l|}
\hline Research field & Number of publications \\
\hline Teaching and learning & 81 \\
\hline Management, leadership \& policy & 56 \\
\hline Technology in education & 30 \\
\hline Psychology education & 20 \\
\hline Curriculum & 11 \\
\hline Test and assessment & 8 \\
\hline Research & 2 \\
\hline Other & 2 \\
\hline
\end{tabular}

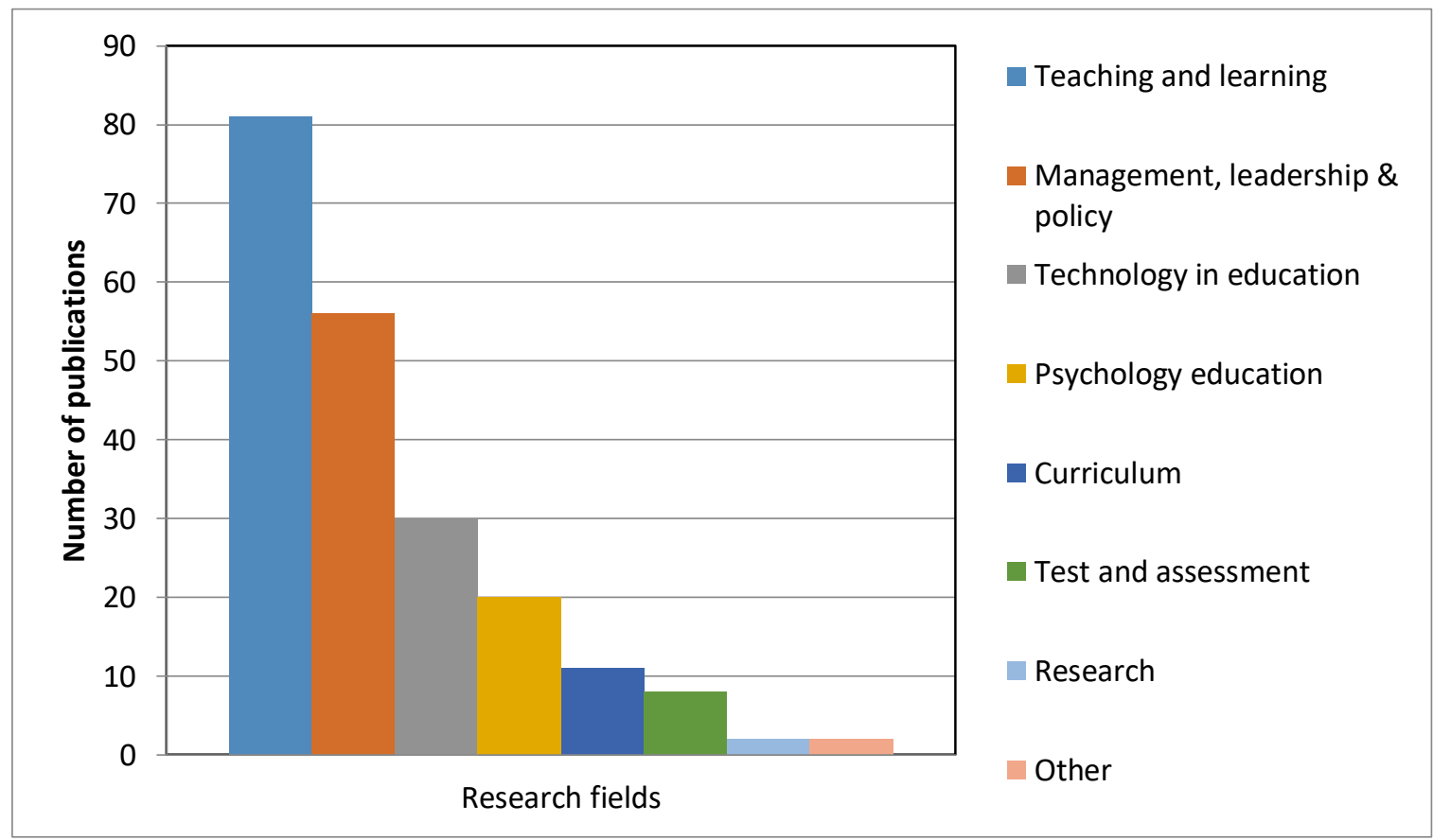

Figure 2. The number of publications in each education research field

It can be obviously seen from the table and the chart above that the highest number of articles are published in "teaching and learning" field. Its total papers are 81, which is followed by "Management, leadership \& policy" field with 56 articles, and nearly triples the third most popular field - "technology in education" with 30 articles.

Actually, education research fields have an interrelation with each other, since one article belonging to this field can be put in the same group with another field. For example, the article "Measuring integration of information and communication technology in education: An item response modeling approach" can fit in two categories, technology in education and testing \& assessment.

Most frequently, the papers about technology in education can have their place in teaching and learning strand. Thus, even being classified into a single category, it cannot be 
denied that technology application takes a crucial part in enhancing the quality of teaching and learning process. Also, it can make this process become an interesting journey for both teachers and learners. According to Joyce Waddell (2015), many educators are struggling with integrating progression between technology and education, because they have not found out the real relationship of technological and pedagogical issues. From this point of view, it can be analyzed that the use of modern tools for educating purpose is still poor and need a lot of improvement. Only thirty papers cannot reflect all features of this field, technologyenhanced application, especially for the current 4.0 period. Therefore, predictably, this field will continue becoming hotter and hotter and in the future. To boost education into a higher level, other researchers should invest more time and effort in exploiting this potential field.

Besides, research field, test \& assessment field and curriculum field, with just 2, 8 and 11 papers respectively also need to receive more concern from researchers around the world. When having only a few papers on these topics, it can create a big gap for studiers to explore and have their own papers. In addition, psychology education should have priority in researching as learners' behaviors, emotion and even motivation contribute significantly to the success of learning process, and these factors can form students' conceptual learning. More importantly, in the article "Research trends in science education from 2013 to 2017: a systematic content analysis of publications in selected journals", the authors claimed the role of researching students' conceptual learning and believed in its trendy part in the future of research.

Among five areas of research, including higher education (HE), Lifelong learning (3L), Technical and vocational education and training (TVET), Early childhood education (ECE) and General education (GE), the first mentioned area is the richest land with the highest number of publications ( 99 out of 175 articles). After that, lifelong learning and general education take turn to express their importance with 50 and 19 papers respectively. Next, two fields receive less exploitation are ELE with only 5 papers and TVET with just 1 publication. Table 3 clearly shows the detailed data for all areas investigated.

Table 3. The number of publications in each education area

\begin{tabular}{|l|l|l|}
\hline Research area/ Branch & Number of publications & Percentage \\
\hline Higher education (HE) & 99 & $56,9 \%$ \\
\hline Lifelong learning (3L) & 50 & $28,7 \%$ \\
\hline $\begin{array}{l}\text { Technical and vocational education } \\
\text { and training (TVET) }\end{array}$ & 1 & $0,6 \%$ \\
\hline Early learning education(ELE) & 5 & $2,9 \%$ \\
\hline General education (GE) & 19 & $10,9 \%$ \\
\hline SUM & $\mathbf{1 7 4}$ & $\mathbf{1 0 0} \%$ \\
\hline
\end{tabular}




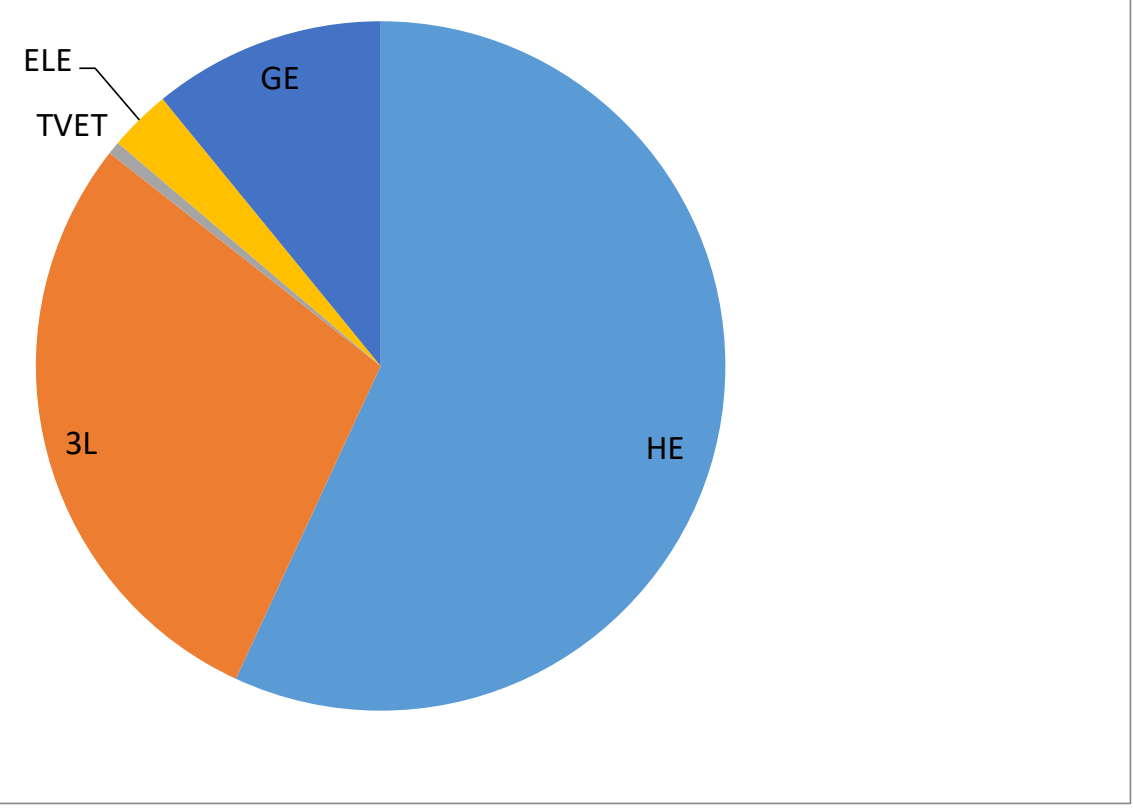

Figure 3. The percentage of publications in each education area

According to the Circular 32/2008/ND-CP on 19, March, 2008 of Vietnam Government, lecturers working in Vietnamese universities need to have at least 600 hours of doing research, that's why more articles were published by university lecturers than teachers of lower level schools. As a common phenomenon, lecturers tend to do research in their own or other related universities to be more convenient. The budget for teachers working in the other places beyond university is still limited, so not many papers have been encouraged to be made in these areas. To diversify the subjects of studies, future researchers should have a clear plan on choosing different participants coming from different schools and levels to balance the scale of research areas, for instance, enhancing the attendance of young children in early learning education or adolescents in TVET- a really potential subject for exploring.

One specific area of research that should be analyzed in more details is general education with its various types, which are primary school, secondary school, high school, multi-grade school and international school. (See table for further information). Surprisingly, the number of published articles about primary school is higher than high school (6 versus 3 papers). Multi-grade and international schools, which are often private educating systems, are becoming more and more popular in Vietnam, but it still gets less attraction than it should be. Since just a few researchers have publications on this area, all people carrying out scientific studies can take advantage of this gap to release more and more related papers.

\section{Main sources of publication}

Figure 4 shows the total number of publications regarding education by Vietnamese authors and their sources between 1990 and 2018 based on the data extracted from the Web of Science. There were 174 papers in total falling into three main sources including journal, book and conference. Among them, journal was the dominant source with 93 publications in 45 different journals followed by book with 45 articles in 32 books. Conference ranked the third with 21 conferences and 36 papers. It can be concluded that having more publications in journals and books is a good signal for researchers in Vietnam since these sources are considered high quality. In contrast, it is much easier to apply as a presenter at a conference and publish the paper in the conference proceedings. 


\section{Number of papers in different sources of publication}

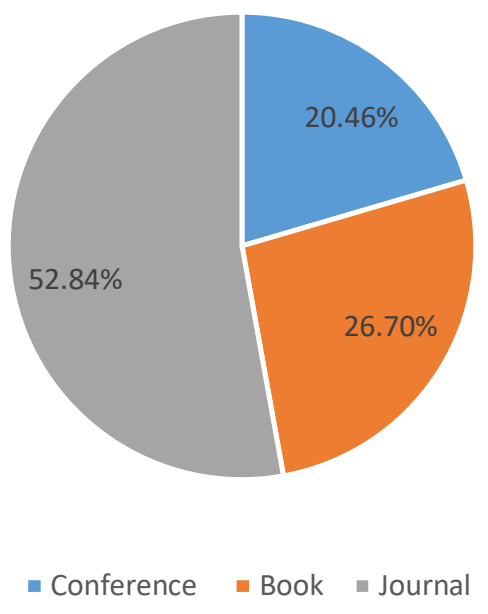

Figure 4. Sources of publication

19 out of 45 book chapters were the collaboration work between Vietnamese and international editors. The rest were edited by international editors only. No work was seen with Vietnamese editor only. In summary, there was a considerable number of book chapters published during the period reviewed; notwithstanding, the contribution of Vietnamese editors was relatively small.

Table 4. Top 5 journals with highest number of publications

\begin{tabular}{|l|l|l|l|}
\hline Number & Journal & Journal IF & Paper \\
\hline 1 & $\begin{array}{l}\text { AIDS } \\
\text { ANDCATION } \\
\text { PREVENTION }\end{array}$ & 1.76 & $\begin{array}{l}\text { 1. Patterns of HIV prevalence and HIV } \\
\text { risk behaviors } \\
\text { among injection drug users prior to and } \\
\text { 24 months following implementation of } \\
\text { cross-border HIV prevention } \\
\text { interventions in Northern Vietnam and } \\
\text { Southern China } \\
\text { 2. Men who have sex with men and HIV } \\
\text { in Vietnam: A review } \\
\text { 3. HIV/AIDS epidemics in Vietnam: } \\
\text { Evolution and responses } \\
\text { 4. Effectiveness of a theory-based risk } \\
\text { reduction HIV } \\
\text { prevention program for rural } \\
\text { Vietnamese adolescents } \\
\text { 5. Influence of perceived secondary } \\
\text { stigma and family on the response to } \\
\text { HIV infection among injection drug } \\
\text { users in Vietnam }\end{array}$ \\
\hline
\end{tabular}




\begin{tabular}{|c|c|c|c|}
\hline & & & $\begin{array}{l}\text { 6. Sex workers in Vietnam: How many, } \\
\text { how risky? } \\
\text { 7. Male homosexual identities, } \\
\text { relationships, and practices among } \\
\text { young men who have sex with men in } \\
\text { Vietnam: implications for HIV } \\
\text { prevention. } \\
\text { 8. Utilization of HIV voluntary } \\
\text { counseling and testing in Vietnam: an } \\
\text { evaluation of } 5 \text { years of routine program } \\
\text { data for national response. } \\
\text { 9. Strategies for developing gender- } \\
\text { specific HIV prevention for adolescents } \\
\text { in Vietnam. } \\
\text { 10. Social desirability response bias and } \\
\text { other factors that may influence self- } \\
\text { reports of substance use and HIV risk } \\
\text { behaviors: a qualitative study of drug } \\
\text { users in Vietnam. } \\
\text { 11. Attitude towards working in rural } \\
\text { area and } \\
\text { self-assessment of competencies in last } \\
\text { year medical students: A survey of five } \\
\text { countries in Asia }\end{array}$ \\
\hline 2 & $\begin{array}{l}\text { COMPUTERS \& } \\
\text { EDUCATION }\end{array}$ & 4.538 & $\begin{array}{l}\text { 1.Automatic summary assessment for } \\
\text { intelligent tutoring systems } \\
\text { 2. ICT in teacher education in an } \\
\text { emerging developing country: } \\
\text { Vietnam's baseline situation at the start } \\
\text { of 'The Year of ICT' } \\
\text { 3. Social question answering: Analyzing } \\
\text { knowledge, cognitive processes and } \\
\text { social dimensions of micro- } \\
\text { collaborations } \\
\text { 4. Measuring integration of information } \\
\text { and communication technology in } \\
\text { education: An item response modeling } \\
\text { approach } \\
\text { 5. RoLo: A dictionary interface that } \\
\text { minimizes extraneous cognitive load of } \\
\text { lookup and supports incidental and } \\
\text { incremental learning of vocabulary } \\
\text { 6. The role of textbook learning } \\
\text { resources in e-learning: A taxonomic } \\
\text { study }\end{array}$ \\
\hline
\end{tabular}




\begin{tabular}{|c|c|c|c|}
\hline 3 & $\begin{array}{l}\text { HIGHER } \\
\text { EDUCATION }\end{array}$ & 1.937 & $\begin{array}{l}\text { 1.A comparative study of research } \\
\text { capabilities of East Asian countries and } \\
\text { implications for Vietnam } \\
\text { 2. Limitation on the development of } \\
\text { skills in higher education in Vietnam } \\
\text { 3.Barriers to and facilitators of female } \\
\text { Deans' career advancement in higher } \\
\text { education: an exploratory study in } \\
\text { Vietnam } \\
\text { 4.Contact hours in Dutch and } \\
\text { Vietnamese higher education: a } \\
\text { comparison } \\
\text { 5. Reforming higher education in } \\
\text { Vietnam: challenges and priorities }\end{array}$ \\
\hline 4 & $\begin{array}{l}\text { INTERNATIONAL } \\
\text { JOURNAL OF } \\
\text { EDUCATIONAL } \\
\text { DEVELOPMENT }\end{array}$ & 1.403 & $\begin{array}{l}\text { 1. Multigrade teaching in Peru, Sri } \\
\text { Lanka and Vietnam: an overview } \\
\text { 2.Linking learning environments } \\
\text { through agricultural experience - } \\
\text { enhancing the learning process in rural } \\
\text { primary schools } \\
\text { 3.Exploring Vietnamese children's } \\
\text { experiences of, and views on, learning } \\
\text { at primary school in rural and remote } \\
\text { communities } \\
\text { 4.Back to school in Afghanistan: } \\
\text { Determinants of school enrollment } \\
\text { 5. Game of blames: Higher education } \\
\text { stakeholders' perceptions of causes of } \\
\text { Vietnamese graduates' skills gap }\end{array}$ \\
\hline 5 & $\begin{array}{l}\text { BMC MEDICAL } \\
\text { EDUCATION }\end{array}$ & 1.938 & $\begin{array}{l}\text { 1.Teacher-made models: the answer for } \\
\text { medical skills training in developing } \\
\text { countries? } \\
\text { 2. Perceptions of graduating students } \\
\text { from eight medical schools in Vietnam } \\
\text { on acquisition of key skills identified by } \\
\text { teachers } \\
\text { 3.Motivation of university and non- } \\
\text { university stakeholders to change } \\
\text { medical education in Vietnam } \\
\text { 4. Propensity score matching in } \\
\text { estimating the effect of managerial } \\
\text { education on academic planning } \\
\text { behavior. Study design: a cross- } \\
\text { sectional study }\end{array}$ \\
\hline
\end{tabular}


Table 4 shows the top 5 journals with the highest number of publications. Among them, "AIDS EDUCATION AND PREVENTION" ranked the first with 11 papers published in it. They were written between the period from 2004 to 2016. Therefore, it can be inferred that AIDS education and prevention has always been the topic that gains much attention from researchers in the field. According to UNAIDS, Vietnam's HIV epidemic has stabilized after reaching the peak in the early 2000s. However, HIV remains a big health issue in Vietnam, with an estimated 11.000 new HIV infections and 7800 AIDS-related deaths in 2016. It's also reported by UNAIDS that, this contagious disease is popular among people who use drugs, gay men and other men who have sex with men and female workers and their sexual partners. These issues were also mentioned in the top 5 mentioned above. COMPUTERS \& EDUCATION was the second journal in the top five. This journal received more publications for the reason that in 2008 the Ministry of Education and Training of Vietnam launched "the year of ICT (Information and Communication Technology)" which has made ITC in educational institutions a top priority. Notetably, this journal was the one owning the highest Impact factor of the 7 journals in the top as well as the highest among the 46 journals. Its impact factor was 4.538 (recorded in 2017) which is considered good in the field. The third position in the rank belonged to two journals namely HIGHER EDUCATION and INTERNATIONAL JOURNAL OF EDUCATIONAL DEVELOPMENT. They both had 5 papers published in. Their impact factors were 1.937 and 1.043 respectively. These impact factors were popular in the field. BMC MEDICAL EDUCATION ranked the fifth with 4 papers in it and its impact factor was 1.983 .

\section{Impact factors}

Figure 5 demonstrates the percentage of publications in each impact factor range. There were 175 papers in total but almost half of them (83 papers) were not published in journals. Instead, they belonged to conferences or books which did not have impact factors. The rest was presented in the chart. There were 4 journals whose IF could not be found including "Anywhere, anytime - Education on demand, Vol 1", "Australia journal of education technology", "Eurasia journal of mathematics science and technology education" and "Women in physics". The number of publications belonging to journals with impact factors ranging from 1.0 to 2.0 was dominant with 55 papers accounting for $51.2 \%$ followed by 16 papers $(17.2 \%)$ in the IF range from $2.0-3.0$ and 12 papers $(12.9 \%)$ ranging from $0-$ 1.0. There were six papers $(6.5 \%)$ belonging to the IF ranging from $3.0-4.0$ which was the highest rank in the chart. This result leads to a conclusion that the number of academic work in high IF journals was relatively small. Considering this issue, Vietnamese researchers should take prompt action to better the situation.

Table 5. The number of publications in each impact factor range

\begin{tabular}{|l|l|l|}
\hline $\begin{array}{l}\text { Impact factor (IF) } \\
\text { range }\end{array}$ & $\begin{array}{l}\text { Numbers } \\
\text { publications }\end{array}$ & of \\
\hline $0-1$ & 12 & $12.9 \%$ \\
\hline $1-2$ & 55 & $51.2 \%$ \\
\hline $2-3$ & 16 & $17.2 \%$ \\
\hline $3-4$ & 6 & $6.5 \%$ \\
\hline $\mathrm{n} / \mathrm{a}$ & 4 & $4.2 \%$ \\
\hline
\end{tabular}




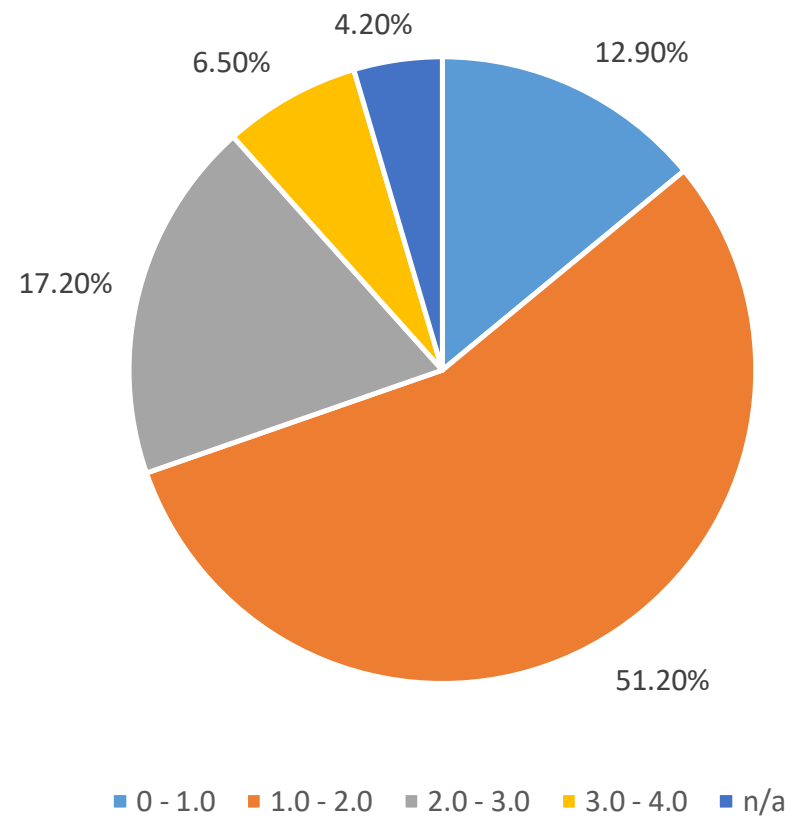

Figure 5. The percentage of publications in each impact factor range

\section{Vietnamese authors' gender}

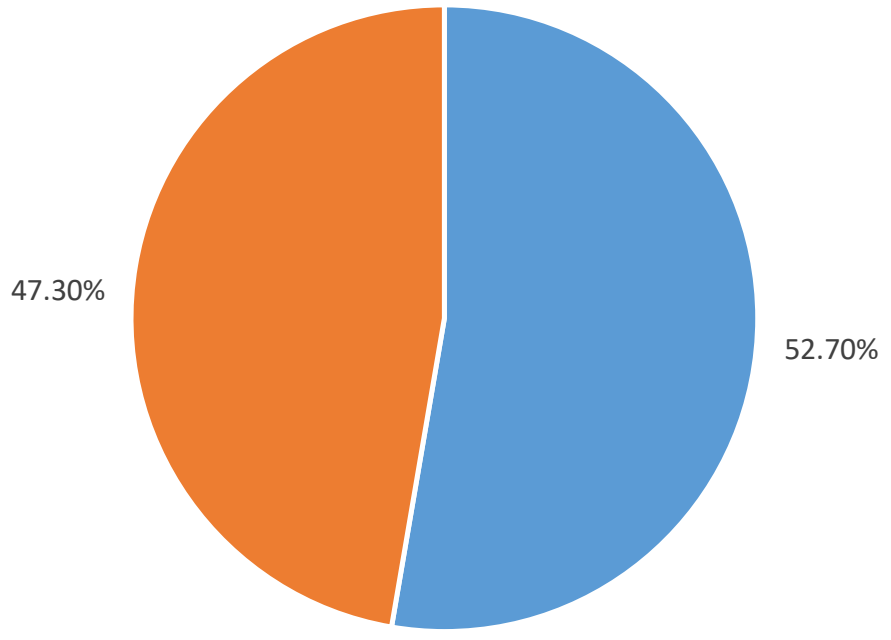

- Vietnamese male authors - Vietnamese female authors

\section{Figure 6. Vietnamese authors' gender}

Figure 6 reveals the number of Vietnamese authors' gender. It can be seen clearly that the number of male and female authors contributing to doing research is relatively equal. Male authors a little bit outnumber female authors with 107 (52.7\%) and 96 (47.3\%) respectively. Nguyễn Thị Thu Hà, chairwoman of Vietnam Women's Union said that over the past ten years saw the improvement in gender equality and the growth of female researchers as a consequence of the nation's top policy in science and technology. There was a gradual increase in the number of women doing research. The proportion of masters' degree earners who are women in 2014 was 43 per cent, of PhD earners was 21 per cent, and of professors 
and associate professors was 24.6 per cent for the 2012-16 period, she said. Many women have conducted outstanding scientific research, laying the foundation for policy making and practical applications, contributing to improving people's lives.

\section{DISCUSSION}

Results of the present study indicate that there were a large number of publications regarding education from Vietnam during the period from 1986 to 2018. The study also shows that the proportion of internationally coauthored papers has slightly increased, suggesting that the research capacity of Vietnam has improved over time.

We would like to further discuss the following points from the findings:

First, it can be concluded that over the period from 1990 to 2018, the number of education articles rose significantly. "Doi Moi" can be considered as the milestone which prepared for the growth of collaboration publishing in education field. With some really slow steps in some first years, in 2009, after exactly one decade, Vietnam's education had an achievement in having certain papers written by authors both inside and outside the country. With the current speed, the number of publications will continue to grow up. However, to support this growing process, the policy from the government and the schools as well need to bed updated and improved frequently.

Higher education is the most popular phrase which was used repeatedly in the publications investigated. In addition, researchers seem to show more interest for this subject of study. Regardless, it should not be ignored that the real requirement about research hour for the lecturers is the driving force to foster the new articles released. Therefore, if there is one policy in which researching in the other levels is encouraged and motivated, there will be more articles written by teachers teaching different grades. Policy is external motivation for researchers, and inspiration is internal one. If researchers are aware of the importance in exploring different group of students, not only university ones, more papers with higher quality can be produced.

Inequality in the number of papers published by dissimilar areas in the country is one remarkable point that should be noted. The quantity of school in those areas is also the factor leading to this imbalance. Where there are more schools, there are more publications. Moreover, the bigger, the more famous and more modern the universities are, the more papers they may have. Some international or private universities like RMIT, Ton Duc Thang may invest a lot in researching activity to promote their school, thus, having more papers is something achievable for them. To boost the fame and the quality, all other schools should have solution to inspire and encourage researchers to write and publish more papers.

The data were extracted from the Web of Science between 1986 and 2018, but not until 2008 was the first collaboration work about education about Vietnam published in an international journal. A big question raised: why was there no paper published during that period? There was a project called 322 launched in 2000 by the Ministry of Education of Vietnam. This project financially supported people who worked in education to study abroad to broaden their knowledge so that they could apply what they had learned to build a better education in Vietnam. Hence, there should have collaborating papers published in international journals before 2008.

The number of papers written by only Vietnamese authors and that by international collaboration were 73 papers and 91 papers respectively. This results suggested that Vietnam is on the way to grow its scientific research capacity, which is characterized by a high level of international collaborations. The increase in the number of international collaboration work doesn't mean that it's a great sign for Vietnamese scientific research since it indicates dependence on other countries for research capacity. Among 175 papers filtered, 93 papers belonged to journals. The rest belonged to conferences or books. Conference rules are not 
strict, so it is not difficult to have a paper published in conference proceedings. The papers published in journals are few and far between. The journal which had the most papers published in, 6 papers, was the one with 4.54 impact factor. This is the highest impact factor among 93 journals mentioned in the results. Most of the papers were published in journals with impact factor ranging from 1.0 to 2.0. Impact factor is commonly used to evaluate the relative importance of a journal within its field and to measure the frequency with which the "average article" in a journal has been cited in a particular time period. Journal which publishes more review articles will get highest IFs. Journals with higher IFs believed to be more important than those with lower ones. According to Eugene Garfield "impact simply reflects the ability of the journals and editors to attract the best paper available." Journal which publishes more review articles will get maximum IFs. Vietnamese researchers should think about the quality of their work since there were not many papers published in journal with high impact factors in the field.

In the summary, with all effort from writer, this review, hopefully, can be beneficial for people with research passion; and it can also inspire and encourage ideas for education research to blossom in the future. 


\section{REFERENCES}

Hien, P. D. (2010). A comparative study of research capabilities of East Asian countries and implications for Vietnam. Higher Education, 6o(6), 615-625.

Lin, T. J., Lin, T. C., Potvin, P., \& Tsai, C. C. (2019). Research trends in science education from 2013 to 2017: a systematic content analysis of publications in selected journals. International Journal of Science Education, 41(3), 367-387.

Manh, H. D. (2015). Scientific publications in Vietnam as seen from Scopus during 19962013. Scientometrics, 105(1), 83-95.

Nguyen, T. V., \& Pham, L. T. (2011). Scientific output and its relationship to knowledge economy: an analysis of ASEAN countries. Scientometrics, 89(1), 107-117.

Vuong, Q.-H., La, V.-P., Vuong, T.-T., Ho, M.-T., Nguyen, H.-K. T., Nguyen, V.-H., ... Ho, M.-T. (2018). An open database of productivity in Vietnam\&\#39;s social sciences and humanities for public use. Scientific Data, 5, 180188. Retrieved from https://doi.org/10.1038/sdata.2018.188

Vuong, Q. H., Napier, N. K., Ho, T. M., Nguyen, V. H., Vuong, T. T., Pham, H. H., \& Nguyen, H. K. T. (2018). Effects of work environment and collaboration on research productivity in Vietnamese social sciences: evidence from 2008 to 2017 scopus data. Studies in Higher Education, o(o), 1-16. https://doi.org/10.1080/03075079.2018.1479845

Waddell, J. (2015). The Role of Technology in the Educational Process. Retrieved from Green and Write Michigan State University: https://edwp. educ. msu. edu/green-and-write/2015/therole-of-technology-in-the-educational-process. 